\title{
Histopathological Types of Papillary Thyroid Carcinoma: Clinicopathologic Study
}

\author{
Zainab Khalid Almukhtar* \\ Department of Pathology, College of Medicine, University of Baghdad, Baghdad, Iraq
}

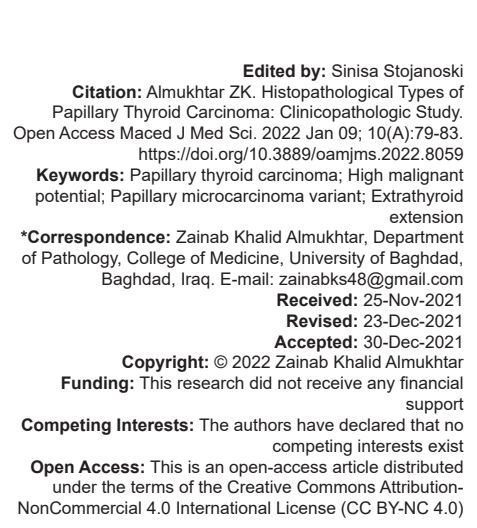

Introduction

Papillary thyroid carcinoma (PTC) is the most common type of thyroid carcinoma which represents more than $70-90 \%$. Papillary carcinoma is a set of characteristic of nuclear features in which the diagnosis is depend, as alteration in nuclear shape and size (overlapping and enlargement of nuclei), margination and clearing of chromatin, glassy appearance of nuclei, irregularity in nuclear contour, grooving nuclei, and presence of nuclear pseudoinclusions [1]. In Iraq, thyroid carcinoma (accounting for $1.7 \%$ of newly diagnosed malignancies, $2.75 \%$ of female cancers, it ranked tenth among the ten most common tumors, according to the latest Iraqi Cancer Registry [2]. There are many subtypes of PTC according to the 2017 WHO classification [3]. Subtyping is depend on a combination of architectural features, cytologic characteristic presence or absence of capsule, and size of growth [4]. BRAFV600E is the most frequent mutation, especially in classic and tall cell subtypes [3]. There is an increasing number of PTC in the past 15-20 years due to increasing identification of thyroid lesions on imaging [5], Hashimoto thyroiditis, and ionizing radiation early in life possible most common causes [6]. Clinically, its presentation is painless thyroid nodule or lump or as a mass in neck or as cervical node and on scanning, it is cold [7], with general excellent prognosis [8]. Surgery alone or in combination with post-operative radiotherapy is the main stay of the management [9]. The aim of this study is to review different variants of PTC in correlation with many prognostic and clinical factors in Iraq.

\section{Methods}

\section{Study design and setting}

This is a retrospective study conducted in Pathology Department, College of Medicine, University of Baghdad. About 227 cases of PTC were collected from teaching laboratories of Baghdad Medical City, at the period from January 2019 to January 2021.

\section{Data collection and sources}

Cases distributed as lobectomy, near total or total thyroidectomy, and total thyroidectomy with nodal 
neck dissection. Final histopathological detection of PTC including various variants was distinguished, using several parameters including: Gender, age, histopathologic type, size of tumor (maximum diameter), focality, side of involvement, associated conditions, encapsulation, vascular invasions, status of lymph nodes, presence of dedifferentiation, extrathyroid extension, and staging. In term of descriptive purposes, the aggressive variants were found in this study including Hobnail, columnar cell variant, and diffuse follicular variant PTC. They classified as high malignant potential and other variants were low to intermediate malignant potential. Preoperatively, all patients underwent clinical and ultrasound evaluation. Paraffin blocks were obtained for all cases and sections were stained with hematoxylin and eosin ( $\mathrm{H}$ and $\mathrm{E})$. Then, all slides were re-examined and findings were documented. The dependence on histopathologic and sonographic records in interpretation involvement lymph node or not, any case with loss of any of the above mentioned variables was excluded from the study.

\section{Ethics committee}

Approval was obtained from the Institutional Review Board of Teaching Laboratories of Baghdad Medical City, which relinquishes the requirement for informed consent due to the retrospective nature of the study.

\section{Statistical analysis}

It was performed with the Statistical Package for the Social Sciences 26 statistical software program. Univariate data were summarized using standard descriptive statistics and tabulation of categorical variables. Associations between categorical variables were assessed through cross tabulation and Chi-square. Exact tests were used to calculate the $p$ value. T-test with bootstrapping was used to compare means of continuous variables. In all statistical analyses, $p<0.05$ was considered significant.

\section{Results}

The mean age was $39.29 \pm 12.172$ years (range 11-86 years) and the most were women (86.3\%). Cases were divided into below 40 years 126 (55.5\%) and above and equal to 40 years 101 (44.5\%). Right lobe was the most frequent lobe that involved by cancer in $44.1 \%$. The mean tumor size was larger in high malignant potential group (Mean $=2.16 \pm 1.24 \mathrm{~cm}$ ) than low malignant potential group (Mean $=1.64 \pm 1.22 \mathrm{~cm}$ ), and this difference was significant $(-0.52041,95 \% \mathrm{Cl}$ $[-1.02215,-0.05388], \mathrm{t}=-2.171, \mathrm{p}=0.03)$. Regarding histopathologic types, 91 cases were conventional type $(40.1 \%)$ which is the most common variant followed by papillary microcarcinoma variant in 67 cases $(11.9 \%)$
Table 1: Distribution of variables

\begin{tabular}{ll}
\hline Characteristic & Frequency (\%) \\
\hline Histopathologic types & \\
Papillary carcinoma, conventional type & $91(40.1)$ \\
Papillary microcarcinoma & $67(29.5)$ \\
Encapsulated variant & $27(11.9)$ \\
Diffuse follicular variant & $25(11.0)$ \\
Encapsulated follicular variant & $3(1.3)$ \\
Columnar cell variant & $2(0.9)$ \\
Invasive encapsulated follicular variant & $5(2.2)$ \\
Hobnail papillary thyroid carcinoma & $3(1.3)$ \\
Warthin-like variant & $2(0.9)$ \\
Mixed: Conventional and microcarcinoma & $2(0.9)$ \\
Histopathologic subtypes according to the malignant potential & \\
Low to intermediate malignant potential & $197(86.8)$ \\
High malignant potential & $30(13.2)$ \\
Tumor stage (AJCC/TNM Staging) & \\
Stage-I & $214(94.3)$ \\
Stage-II & $10(4.4)$ \\
Stage-III & $1(0.4)$ \\
Stage-IV B & $2(0.9)$ \\
Tumor focality & $160(70.5)$ \\
Unifocal & $67(29.5)$ \\
Multifocal & \\
Capsular invasion & $38(16.7)$ \\
Present & $189(83.3)$ \\
Absent & \\
Lymph nodes involvement & $55(24.2)$ \\
Involved & $172(75.8)$ \\
Not involved & \\
Vascular invasion & $62(27.3)$ \\
Present & $165(72.7)$ \\
Absent & \\
Extrathyroid extension & $25(11.0)$ \\
Present & $202(89.0)$ \\
Absent & \\
Distant metastasis & $17(7.5)$ \\
Present & $210(92.5)$ \\
Absent &
\end{tabular}

(which is PTC that is equal to or $<1 \mathrm{~cm}$ ) and other variants are shown in Table 1. Histopathologic subtypes according to the malignant potential were distributed as followed, 197 cases $(86.8 \%)$ were low to intermediate malignant potential, while 30 cases $(13.2 \%)$ were grouped as high malignant potential, which includes variants with aggressive behavior (columnar cell, hobnail, and diffuse infiltrative follicular variants). The present work has been confirmed that $(65.2 \%)$ of cases were detected without need to ancillary studies like immunohistochemistry stains due to characteristic nuclear features that papillary carcinoma diagnosis is based. In our center, CK 19 positivity and occasionally with combination of CD56 negativity were used (Figure 1). Other frequencies concerning tumor stage, tumor focality, native capsular invasion, lymph nodes involvement, presence or absence of vascular invasion, extrathyroid extension, and distant metastasis are presented in Table 1, while correlation between low to intermediate malignant potential subtypes and high malignant potential subtypes regarding various prognostic factors are illustrated in Table 2.

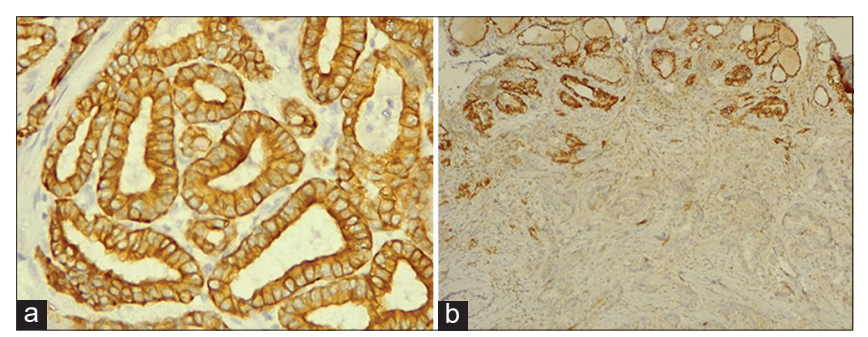

Figure 1: (a) Positive CK19 (prominent membranous and cytoplasmic staining), (b) PTC is negative for CD56 (below), while the normal follicles are positive 


\section{Discussion}

The mostcommonvariantof PTC is conventional in $40.1 \%$, followed by papillary microcarcinoma in $29.5 \%$, which agree Singhal et al. [10] study. Women are the most common documented in $86.3 \%$, which supporting with Siegel et al. [11] study. The mean age of patients is ( $39.29 \pm 12.17$ years), which is lower than mean age of Cho et al. [12] study. This is may be due to possibility that Iraqi people being exposed to radiation (which is important risk factor) due to repeated wars in Iraq in the past three decades. About 126 of the cases were aged below 40 years. Approximately $86.1 \%$ of cases belonged to the low to intermediate malignant potential variants and others classified as high malignant potential. This explained by unusual external circumstances, mean that the Iraqi people had been exposed to different external radiation during several wars, in addition to different age distribution between different variants, for example, high malignant potential variants occur usually in older patient than those of classic papillary thyroid variant and the microcarcinoma, which both are major components of first group. Multifocality figured nearly in $30 \%$. The papillary carcinoma is the most frequent type of well-differentiated thyroid carcinoma known as multifocal. The multifocality is considered as an independent risk factor of PTC recurrence after surgical removal and the TNM stages were higher, yet, there is no significant association between low to intermediate malignant potential and high malignant potential. There are 60 cases in the first group, while seven cases in the second group of papillary thyroid microcarcinoma, this is may be due to an increment in the incidence of papillary thyroid microcarcinoma in the past decades [13]. Hashimoto's thyroiditis is the most common autoimmune lymphocytic thyroiditis. The relation of Hashimoto's disease to papillary carcinoma has been broadly correlated [14]. In this study, 25 cases $(11.0 \%)$ of all cases were correlated with Hashimoto's disease, this percentage is less than parentage seen in other studies like Graceffa et al., whereas $70 \%$ of cases are associated with multinodular colloid goiter, both conditions have a 1.6 times increased risk of incidence of PTC [15], the reason beyond, it is may be the effect of other carcinogens in pathogenesis of PTC in Iraq like exposure to radiation and chemical toxicants. In relation to lymph nodes spreading, $24.2 \%$ of cases showed metastasis in the lymph nodes of the neck, where $(90.9 \%)$ those of low to intermediate malignant potential and $(9.1 \%)$ of high-grade malignant potential, this is, in contrast to other studies stated that aggressive variants had high rate of lymph node metastasis reaching up to $70 \%$ [16]. It is important to notify that lymph node metastases of the PTC are a sensible prognostic factor and a key for recurrence of the tumor, but not for survival as concluded by Maksimovic et al. [17]. Distant metastasis is the main cause of PTC mortality [18], which has been reported in (9-14\%) during its clinical
Table 2: Cross tabs (Chi-square tests of independence)

\begin{tabular}{|c|c|c|c|}
\hline \multirow[t]{3}{*}{ Characteristic } & \multicolumn{2}{|c|}{$\begin{array}{l}\text { Histopathologic subtypes according to the } \\
\text { malignant potential }\end{array}$} & \multirow[t]{3}{*}{$\begin{array}{l}\text { Fisher's Exact } \\
\text { Test }(p)\end{array}$} \\
\hline & $\begin{array}{l}\text { Low to intermediate } \\
\text { malignant potential } n=197\end{array}$ & $\begin{array}{l}\text { High malignant } \\
\text { potential } n=30\end{array}$ & \\
\hline & $\mathrm{n}(\%)$ & $\mathrm{n}(\%)$ & \\
\hline \multicolumn{4}{|l|}{ Age groups } \\
\hline$<40$ years & $110(87.3)$ & $16(12.7)$ & \multirow{2}{*}{0.845 (NS) } \\
\hline$\geq 40$ years & $87(86.1)$ & $14(13.9)$ & \\
\hline \multicolumn{4}{|l|}{ Gender } \\
\hline Female & $172(87.8)$ & $24(12.2)$ & \multirow[t]{2}{*}{0.26 (NS) } \\
\hline Male & $25(80.6)$ & $6(19.4)$ & \\
\hline \multicolumn{4}{|l|}{ Tumor focality } \\
\hline Unifocal & $137(85.6)$ & $23(14.4)$ & \multirow[t]{2}{*}{0.52 (NS) } \\
\hline Multifocal & $60(89.6)$ & $7(10.4)$ & \\
\hline \multicolumn{4}{|l|}{ Pathologic background } \\
\hline Hashimoto thyroiditis & $23(92.0)$ & $2(8.0)$ & \multirow[t]{2}{*}{0.54 (NS) } \\
\hline Other pathologies & $174(86.1)$ & $28(13.9)$ & \\
\hline \multicolumn{4}{|l|}{ Tumor stage } \\
\hline Stage: I-II & $195(87.1)$ & $29(12.9)$ & \multirow[t]{2}{*}{0.35 (NS) } \\
\hline Stage: III-IV B & $2(66.7)$ & $1(33.3)$ & \\
\hline \multicolumn{4}{|l|}{ Tumor differentiation } \\
\hline Differentiated & $8(100)$ & 0 & \multirow[t]{2}{*}{0.32 (NS) } \\
\hline Dedifferentiated & $189(86.3)$ & $30(13.7)$ & \\
\hline \multicolumn{4}{|l|}{ Capsular invasion } \\
\hline Present & $33(86.8)$ & $5(13.2)$ & \multirow[t]{2}{*}{1.0 (NS) } \\
\hline Absent & $164(86.8)$ & $25(13.2)$ & \\
\hline \multicolumn{4}{|l|}{ Lymph nodes involvement } \\
\hline Involved & $50(90.9)$ & $5(9.1)$ & \multirow[t]{2}{*}{0.21 (NS) } \\
\hline Not involved & $147(85.5)$ & $25(14.5)$ & \\
\hline \multicolumn{4}{|l|}{ Vascular invasion } \\
\hline Present & $57(91.9)$ & $5(8.1)$ & \multirow[t]{2}{*}{0.19 (NS) } \\
\hline Absent & $140(84.8)$ & $25(15.2)$ & \\
\hline \multicolumn{4}{|l|}{ Extrathyroid extension } \\
\hline Present & $21(84)$ & $4(16)$ & \multirow[t]{2}{*}{0.75 (NS) } \\
\hline Absent & $176(87.1)$ & $26(12.9)$ & \\
\hline \multicolumn{4}{|l|}{ Distant metastasis } \\
\hline Present & $14(82.4)$ & $3(17.6)$ & \multirow[t]{2}{*}{0.48 (NS) } \\
\hline Absent & $183(87.1)$ & $27(12.9)$ & \\
\hline
\end{tabular}

course and occur later on [18], supporting these data by a study done by Khan et al. [19]. Similarly, $7.5 \%$ of cases showed distant metastasis with $17.6 \%$ of them belonged to high malignant potential variants. Native capsular invasion of thyroid seen in 38 cases $(16.7 \%)$, the results from one study suggested that existence of capsular invasion did not have adverse outcomes on biological behavior and on long-term prognosis in patients with PTC [20]. Vascular invasion seen in 62 of the cases, this percent is within the range of its incidence in other studies (5.6-33\%), which concluded that a significant variability regarding the relationship between vascular invasions and outcome like recurrence as reported in prior studies [21]. Other studies failed to validate this observation [22]. Extrathyroid extension was seen in 25 of cases, most of them in low to intermediate malignant potential group (about 21 cases). All of the cases in the present study are of minimal invasion, that is, just extension to sternothyroid muscle or perithyroid soft tissues. This type of extension does not enhance $T$ category or affect the mortality and recurrence rates in patients with PTC [23], whereas massive extrathyroid extension was reported to influence those mentioned rates [24]. In view of tumor size, there is a significant correlation between two groups. Primary tumor diameter has been reported as a predictor for outcome in PCT [25]. In the previous studies concluded that tumors which are more than $1 \mathrm{~cm}$ had worse prognosis [26], in which the patients with tumor diameter more than $1 \mathrm{~cm}$ had a higher risk of post-operative recurrence as compared with those whom $<1 \mathrm{~cm}$ and during follow-up of these patients with consideration of other prognostic 
factors [27]. However, there was no statistical difference in survival between them. Another studies retail on a single-size threshold of $2 \mathrm{~cm}$ maximized prognostic distinct in with tumors more than $2 \mathrm{~cm}$ associated with a 5 times higher risk of recurrence than those tumors with $<=2 \mathrm{~cm}$ [28]. Regarding the staging, almost all of the cases were in Stage I or II that is because $92 \%$ of the cases were $<50$ years old considering the cutoff of this age as an essential variable for AJCC staging of differentiated thyroid cancer [29]. Finally, on notification of correlation between the two groups regarding the prognostic factors, this may be elaborate some study limitations as relative small sample size, small number of high malignant potential types of all collected cases, and short duration of the study.

\section{Conclusion}

Conventional type followed by micropapillary type is most common. The mean age in Iraqi patients is lower than other countries. There is no significant association regarding prognostic factors between low to intermediate and high malignant potential variants with exception of the tumor diameter.

\section{References}

1. Nikiforov YE, Seethala RR, Tallini G, Baloch ZW, Basolo F, Thompson LD, et al. Nomenclature revision for encapsulated follicular variant of papillary thyroid carcinoma: A paradigm shift to reduce overtreatment of indolent tumors. JAMA Oncol. 2016;2:1023-9. https://doi.org/10.1001/jamaoncol.2016.0386 PMid:27078145

2. Hussain AM, Lafta RK. Cancer Trends in Iraq 2000-2016. Oman Med J. 2021;36(1):e219. https://doi.org/10.5001/omj.2021.18 PMid:33552559

3. Lloyd RV, Osamura RY, Klöppel G, Rosai J. Who Classification of Endocrine Organs. $4^{\text {th }}$ ed. Lyon, France: IARC; 2017. Available from: https://www.iarc.who.int/news-events/who-classification-oftumours-of-endocrine-organs [Last accessed on 2021 Nov 20].

4. Lloyd RV, Buehler D, Khanafshar E. Papillary thyroid carcinoma variants. Head Neck Pathol. 2011;5(1):51-6. https://doi. org/10.1007/s12105-010-0236-9

PMid:21221869

5. Pellegriti G, Frasca F, Regalbuto C, Squatrito S, Vigneri R. Worldwide increasing incidence of thyroid cancer: Update on epidemiology and risk factors. J Cancer Epidemiol. 2013;2013:965212. https://doi.org/10.1155/2013/965212 PMid:23737785

6. Albi E, Cataldi S, Lazzarini A, Codini M, Beccari T, AmbesiImpiombato FS, et al. Radiation and thyroid cancer. Int J Mol Sci. 2017;18(5):911. https://doi.org/10.3390/ijms18050911 PMid:28445397

7. Bomeli SR, LeBeau SO, Ferris RL. Evaluation of a thyroid nodule. Otolaryngol Clin North Am. 2010;43(2):229-38, 7. https://doi.org/10.1016/j.otc.2010.01.002

PMid:20510711

8. Ito $Y$, Miyauchi A, Kihara M, Fukushima M, Higashiyama $T$, Miya A. Overall survival of papillary thyroid carcinoma patients: A single-institution long-term follow-up of 5897 patients. World J Surg. 2018;42(3):615-22. https://doi.org/10.1007/ s00268-018-4479-z

PMid:29349484

9. Nguyen QT, Lee EJ, Huang MG, Park YI, Khullar A, Plodkowsk RA. Diagnosis and treatment of patients with thyroid cancer. Am Health Drug Benefits. 2015;8(1):30-40.

PMid:25964831

10. Singhal S, Sippel RS, Chen H, Schneider DF. Distinguishing classical papillary thyroid microcancers from follicular-variant microcancers. J Surg Res. 2014;190(1):151-6. https://doi. org/10.1016/j.jss.2014.03.032 PMid:24735716

11. Siegel RL, Miller KD, Jemal A. Cancer statistics, 2018. CA Cancer J Clin. 2018;68(1):7-30. https://doi.org/10.3322/ caac. 21442 PMid:29313949

12. Cho JS, Yoon JH, Park MH, Shin SH, Jegal YJ, Lee JS, et al Age and prognosis of papillary thyroid carcinoma: Retrospective stratification into three groups. J Korean Surg Soc. 2012;83(5):259-66. https://doi.org/10.4174/jkss.2012.83.5.259 PMid:23166884

13. Ng SC, Kuo SF, Chen ST, Hsueh C, Huang BY, Lin JD. Therapeutic outcomes of patients with multifocal papillary thyroid microcarcinomas and larger tumors. Int J Endocrinol. 2017;2017:4208178. https://doi.org/10.1155/2017/4208178 PMid:28642790

14. Selek A, Cetinarslan B, Tarkun I, Canturk Z, Ustuner B, Akyay Z. Thyroid autoimmunity: Is really associated with papillary thyroid carcinoma? Eur Arch Otorhinolaryngol. 2017;274(3):1677-81. https://doi.org/10.1007/s00405-016-4414-6 PMid:27933384

15. Consorti F, Loponte M, Milazzo F, Potasso L, Antonaci A. Risk of malignancy from thyroid nodular disease as an element of clinical management of patients with Hashimoto's thyroiditis. Eur Surg Res. 2010;45(3-4):333-7. https://doi.org/10.1159/000320954 PMid:21051899

16. Lubitz CC, Economopoulos KP, Pawlak AC, Lynch K, DiasSantagata D, Faquin WC, et al. Hobnail variant of papillary thyroid carcinoma: An institutional case series and molecular profile. Thyroid. 2014;24(6):958-65. https://doi.org/10.1089/ thy. 2013.0573

PMid:24417340

17. Maksimovic S, Jakovljevic B, Gojkovic Z. Lymph node metastases papillary thyroid carcinoma and their importance in recurrence of disease. Med Arch. 2018;72(2):108-11. https://doi. org/10.5455/medarh.2018.72.108-111 PMid:29736098

18. Lee J, Soh EY. Differentiated thyroid carcinoma presenting with distant metastasis at initial diagnosis, clinical outcomes and prognostic factors. Ann Surg. 2010;251(1):114-9. https://doi. org/10.1097/SLA.0b013e3181b7faf6 PMid:19779325

19. Khan U, Al Afif A, Aldaihani A, MacKay C, Rigby $M H$, Rajaraman $\mathrm{M}$, et al. Patient and tumor factors contributing to distant metastasis in well-differentiated thyroid cancer: A retrospective cohort study. J Otolaryngol Head Neck Surg. 2020;49(1):78. https://doi.org/10.1186/s40463-020-00469-8 PMid:33198797

20. Furlan JC, Bedard YC, Rosen IB. Significance of tumor capsular 
invasion in well-differentiated thyroid carcinomas. Am Surg 2007;73(5):484-91.

PMid: 17521005

21. Wreesmann VB, Nixon IJ, Rivera M, Katabi N, Palmer F, Ganly I, et al. Prognostic value of vascular invasion in well-differentiated papillary thyroid carcinoma. Thyroid. 2015;25(5):503-8. https:// doi.org/10.1089/thy.2015.0052

PMid:25748079

22. Furlan JC, Bedard YC, Rosen IB. Clinicopathologic significance of histologic vascular invasion in papillary and follicular thyroid carcinomas. J Am Coll Surg. 2004;198(3):341-8. https://doi. org/10.1016/j.jamcollsurg.2003.11.012

PMid:14992733

23. Nixon IJ, Ganly I, Patel S, Palmer FL, Whitcher MM, Tuttle RM, et al. The impact of microscopic extrathyroid extension on outcome in patients with clinical T1 and T2 well-differentiated thyroid cancer. Surgery. 2011;150(6):1242-9. https://doi. org/10.1016/j.surg.2011.09.007

PMid:22136847

24. Hu A, Clark J, Payne RJ, Eski S, Walfish PG, Freeman JL. Extrathyroidal extension in well-differentiated thyroid cancer: Macroscopic vs microscopic as a predictor of outcome. Arch Otolaryngol Head Neck Surg. 2007;133(7):644-9. https://doi. org/10.1001/archotol.133.7.644

PMid: 17638775

25. Edge SB, Compton CC. The American joint committee on cancer: The $7^{\text {th }}$ edition of the AJCC cancer staging manual and the future of TNM. Ann Surg Oncol. 2010;17(6):1471-4. https:// doi.org/10.1245/s10434-010-0985-4

PMid:20180029

26. Bilimoria KY, Bentrem DJ, Ko CY, Stewart AK, Winchester DP, Talamonti MS, et al. Extent of surgery affects survival for papillary thyroid cancer. Ann Surg. 2007;246(3):375-81; discussion 381-4. https://doi.org/10.1097/SLA.0b013e31814697d9 PMid: 17717441

27. Zhang TT, Li CF, Wen SS, Huang DZ, Sun GH, Zhu YX, et al. Effects of tumor size on prognosis in differentiated thyroid carcinoma smaller than $2 \mathrm{~cm}$. Oncol Lett. 2019;17(5):4229-36. https://doi.org/10.3892/ol.2019.10088

PMid:30944617

28. Tran B, Roshan D, Abraham E, Wang L, Garibotto N, Wykes J, et al. The prognostic impact of tumor size in papillary thyroid carcinoma is modified by age. Thyroid. 2018;28(8):991-6. https://doi.org/10.1089/thy.2017.060 PMid:29921174

29. Amin MB, Greene FL, Edge SB, Compton CC, Gershenwald JE, Brookland RK, et al. The eighth edition AJCC cancer staging manual: Continuing to build a bridge from a populationbased to a more "personalized" approach to cancer staging. CA Cancer J Clin. 2017;67(2):93-9. https://doi.org/10.3322/ caac. 21388

PMid:28094848 